\title{
Current Archaeological Investigations at the Pilgrim's Pride Site (41CP304) In Camp County, Texas
}

Timothy K. Perttula

Heritage Research Center, Stephen F. Austin State University

Follow this and additional works at: https://scholarworks.sfasu.edu/ita

Part of the American Material Culture Commons, Archaeological Anthropology Commons, Environmental Studies Commons, Other American Studies Commons, Other Arts and Humanities Commons, Other History of Art, Architecture, and Archaeology Commons, and the United States History Commons

Tell us how this article helped you.

This Article is brought to you for free and open access by the Center for Regional Heritage Research at SFA ScholarWorks. It has been accepted for inclusion in Index of Texas Archaeology: Open Access Gray Literature from the Lone Star State by an authorized editor of SFA ScholarWorks. For more information, please contact cdsscholarworks@sfasu.edu. 


\section{Current Archaeological Investigations at the Pilgrim's Pride Site (41CP304) In Camp County, Texas}

\section{Creative Commons License}

\section{(c) (1) \&}

This work is licensed under a Creative Commons Attribution-NonCommercial 4.0 International License 


\title{
CURRENT ARCHEOLOGICAL INVESTIGATIONS AT THE PILGRIM'S PRIDE SITE (4ICP304) IN CAMP COUNTY, TEXAS
}

\author{
Timothy K. Perttula
}

\section{INTRODUCTION}

The Pilgrim's Pride site (41CP304) is a large $(12+$ acres $)$ Archaic and Late Caddoan Titus phase site on the crest of a projecting upland landform overlooking, and $18 \mathrm{~m}$ above, the Big Cypress Creek floodplain to the east and the Walkers Creek floodplain to the south. The site is marked by several concentrations of ceramic sherds, midden deposits, and various features (including burials) from the Late Caddoan Titus phase component, along with at least one area in the eastern part of the site with Middle-Late Archaic tools, lithic debris, and fire-cracked rock. No features of Middle-Late Archaic age have been identified at the Pilgrim's Pride site, and it is doubtful that intact archeological deposits or features of Archaic age are preserved on the stable upland landform. Consequently, our winter 1999 investigations in advance of construction of a rendering plant by Pilgrim's Pride Corporation were on the better preserved Late Caddoan Titus phase component. The initial analysis of the decorated sherds from the Pilgrim's Pride site suggests it was occupied primarily during the 15th and 16th centuries (Perttula and Nelson 1998a:30, 1998b:4), and this has been recently confirmed by three radiocarbon dates we secured on charred nutshells from three features (Table 1). Our temporal estimate of the occupational span of the site will be further refined following the completion of the ceramic analyses, along with the analysis of radiocarbon and Oxidizable Carbon Ratio dates from features.

The data recovery investigations were initiated on January 27, 1999, and completed on February 17, 1999. Members of the Caddo Indian Tribe of Oklahoma, specifically from the Historic Preservation Office and the Native American Graves Protection and Repatriation Act Office, were involved in all aspects of the proposed field investigations at the Pilgrim's Pride site. In particular, 4 - 5 tribal members participated in excavations efforts as members of the archeological team. 
Table 1. Available Radiocarbon Dates from the Pilgrim's Pride Site.

\begin{tabular}{|c|c|l|c|c|}
\hline Sample \# & Area & Context & $\begin{array}{c}\text { Calibrated Age Ranges } \\
\text { (2 sigma) }\end{array}$ & $\begin{array}{c}\text { Relative Cont. } \\
\text { to Probabilities }\end{array}$ \\
\hline \hline Beta-125985 & I & Fea. 3 & AD 1447-1642 & 1.00 \\
\hline Beta-125986 & III & Sheet Midden & AD 1471-1648 & 0.98 \\
\hline Beta-125987 & II & Midden & AD 1388-1660 & 0.97 \\
\hline
\end{tabular}

During the investigations, approximately $9450 \mathrm{~m}^{2}$ were stripped with a bulldozer and backhoe in six different areas of the Pilgrim's Pride site, and 351 cultural features were identified and excavated in these areas. Monitoring of another 4000 $\mathrm{m}^{2}$ area identified another $20+$ features, including portions of a circular house pattern. Among the features identified and excavated at the Pilgrim's Pride site are 20
Late Caddoan Titus phase burials, a complete circular house pattern (House 1), and more than 90 pits. A $11 \mathrm{~m}$ long backhoe trench and $\mathrm{a} 1 \times 2.6 \mathrm{~m}$ unit were excavated in the northeastern part of the site to investigate a possible Late Caddoan Titus phase earthen mound, and our work confirmed that the Pilgrim's Pride site contains an earthen mound built over a burned structure.

\section{Area I}

Area I, the northwestern site area, is apparently the most intensively occupied part of the Titus phase community at the Pilgrim's Pride site. Bulldozer-backhoe scraping and shovel skimming of $2300 \mathrm{~m}^{2}$ documented 197 features, including a complete posthole pattern of a circular structure (House 1), one burial (Fea. 1128) south of the structure that contained two whole vessels, and 41 pit features. These pit features are concentrated in two clusters south and west of House 1, and the south cluster of pits appears to have also been in a midden area. A third feature cluster in the southwestern part of Area I has a number of postholes and one large basin-shaped pit, and may represent another household area in this part of the site.

House 1 is approximately $7 \mathrm{~m}$ in diameter, with an entrance facing south. The walls of the structure are defined by regularly-spaced posts about $15 \mathrm{~cm}$ in diameter. There are a number of interior posts, especially on the eastern side of the house, that may mark interior partitions or benches, as well as at least six smudge pits (Fea. 110, 111, 114, 188, 191, and 1-244) within one $m$ of the house wall. Fea. 183 
Volume 10(2)

represents the central support post, and it was probably under a shallow hearth that would have been in the plow zone.

The majority ( 56 percent) of the pit features are relatively deep $(20-40 \mathrm{~cm})$ pits between $30-40 \mathrm{~cm}$ in diameter, and they contain abundant nutshells, charred maize cupules and cob fragments, small pieces of bone, and ceramic sherds and an occasional piece of lithic debris. The shallower pits (less than $15 \mathrm{~cm}$ in depth below the scraped surface) have a dark carbon-rich fill, and may be smudge pits.

\section{Area II}

Two Titus phase feature clusters were identified in Area II, immediately east of Area I, during the machine scraping and shovel-skimming investigations. A total of 46 features were identified and excavated in the $1100 \mathrm{~m}^{2}$ block.

Pit features were very common (representing 61 percent of the features), along with midden debris, suggesting that the archeological deposits here are primarily the product of outdoor activities and trash disposal. Deeper pits (ca. $40 \mathrm{~cm}$ in diameter and $20-40 \mathrm{~cm}$ in depth below the scraped surface) are also notable in Area II, comprising 33 percent of the features, compared to 12 percent of the features in Area I and 6 percent of the features in Area III. The other features in Area III include 17 postholes, probably from outdoor racks or ramadas/arbors rather than a house structure, and one small clay-filled pit that contained a single sherd.

\section{Area III}

Approximately $2800 \mathrm{~m}^{2}$ were stripped from Area III (about $50 \mathrm{~m}$ south of Area II) with a bulldozer and backhoe, and 40 percent in the central and northern part of the block was subsequently shovel skimmed and troweled to accurately identify cultural features. A total of 82 cultural features were identified and excavated in Area III, principally in two feature clusters on the highest elevation of the natural rise on this part of the Pilgrim's Pride site. The features include 53 postholes, one possible hearth, 23 small, shallow pits, and five deep (i.e., $>15 \mathrm{~cm}$ in depth below the scraped surface) pits with dark carbon-rich sediments and an abundance of charred nutshells and cultural materials. Although no clear house patterns were defined in this area, it is suspected that the feature clusters represent Titus phase household and outdoor activity areas. 


\section{Area IV}

Area IV consisted of a $1500 \mathrm{~m}^{2}$ block in the central part of the site (on a small rise) that was stripped with a bulldozer and backhoe, and then shovel-skimmed to look for cultural features. Only a single cultural feature -- a posthole (Fea. 401) -was identified in Area IV. The excavation of two $1 \times 1 \mathrm{~m}$ units on the rise (see Figure 1) recovered less than 10 artifacts per unit, indicating a very sparse Titus phase occupation here. It is suspected that Area IV represents a centrally-located plaza in the Titus phase settlement.

\section{Area V and VI}

Area $\mathrm{V}$ is situated on the highest natural rise (330 feet amsl) on the Pilgrim's Pride site, more than $100-150 \mathrm{~m}$ south and southwest of Areas I and II, and west of Area III. Bulldozer and backhoe stripping of approximately $1150 \mathrm{~m}^{2}$ identified a discrete Late Caddoan Titus phase cemetery on the southern part of the rise. A total of 19 individual burials were identified and excavated in the cemetery, and these burials are distributed in three roughly north-south rows. The southernmost burial (Fea. 70) was exposed in a road cutbank.

As part of the excavations of the burial and funerary objects, a Caddo Tribe of Oklahoma tribal member on the field crew conducted the necessary ceremonies as laid out by the Tribe's Repatriation Committee. The few human remains, the funerary objects, and any associated sediments have been kept together in a sturdy box during the analysis phase of the project, and these materials will be returned to the Caddo Indian Tribe for permanent disposition after the analyses are completed.
The burial pits are oriented east-west, with the head facing west, and the pits were excavated from $20-60 \mathrm{~cm}$ into a dense reddish-gray B-horizon clay. The majority of the burials did not contain any preserved human remains, and in the few burials that did have human remains, the evidence consisted of very poorly preserved skeletal elements and teeth.

The burials were accompanied by different kinds of funerary objects, including ceramic vessels (carinated bowls, compound bowls, jars, and bottles), celts, clay pipes, arrow points, bifaces, and other assorted items. A preliminary inventory of the funerary objects recovered from the Titus phase cemetery includes 100 whole vessels, 26 sherd concentrations (probably representing another 30 - 40 broken vessels), four celts, one clay pipe, 18 arrowpoints, three bifaces (including a two-beveled knife from Fea. 509), four smoothed stones, one mano, green pigment, and a piece of petrified wood with quartz crystals. Based on the funerary objects and the size and depth of the burial pits, there appear to be primarily two 
Volume 10(2)

different kinds of burials at the site: (a) those in deep pits with celts, arrow points, and ceramic vessels (probably adult males) and (b) shallower and smaller pits with ceramic vessels (probably adult females).

The excavation of two $1 \times 1 \mathrm{~m}$ units in Area $\mathrm{V}$, as well as the scraping and shovel skimming work, indicate that there is little to no Titus phase habitation debris on this rise. A $20 \times 30 \mathrm{~m}$ area immediately west of the Titus phase cemetery (Area VI) was carefully stripped with a bulldozer and backhoe to the sterile B-horizon clay, and then shovel scraped, in this area of the site, along with a single $1 \times 1 \mathrm{~m}$ unit. This work identified no features and only very sparse archeological deposits in this part of the Pilgrim's Pride site.

\section{Area VII}

Area VII consists of a small earthen mound in the northeastern part of the Pilgrim's Pride site. Based on our investigations and topographic mapping, the mound appears to have been approximately $6.5 \mathrm{~m}$ in diameter and $50-60 \mathrm{~cm}$ in height. This feature was not identified during previous test investigations by Horizon Environmental Services, Inc.

During our work, we excavated a $11 \mathrm{~m}$ long trench across the probable mound, and the profile of the western wall of the backhoe trench defined a buried yellow sand lens (zone 7) that was flat-lying and about $4 \mathrm{~m}$ in length, and of cultural origin; it contained sherds of Ripley Engraved and a few pieces of animal bone, along with charcoal flecks and small amounts of ash. It rested on a buried brown sandy loam E-horizon. The deposits above the lens were not disturbed -- and zones 2 and 3 were dark grayish-brown to dark reddish-brown deposits of mound fill with significant amounts of charcoal, ash, and some oxidized sand. The mound fill capped the yellow sand lens, and extended only a short distance north of the yellow sand lens, which we believe to be an intentionally-laid house floor deposit. Outside the mound, to the north in the profile, the soil zones appear to be from a deep natural profile of A- and E-horizon sandy loam overlying an orange clay Bhorizon.

The eastern wall of the backhoe trench exposed in cross-section a large ash-filled hearth lying about $60-90 \mathrm{~cm}$ bs, and an irregular-sized unit $(2.6 \times 1 \mathrm{~m})$ was excavated adjacent to the backhoe trench to expose the hearth and any associated features. The hearth (Fea. 71) appears to have been built on the surface of the yellow sand lens or floor, and it was heavily used. The hearth covers an area approximately $120 \times 60 \mathrm{~cm}$ in size at 62 $\mathrm{cm}$ bs (where its top is first clearly exposed), and contains significant deposits of ash, oxidized sand, and charcoal that are a maximum of $40 \mathrm{~cm}$ in thickness above the floor. Midden deposits (zone $4 B$ ) and a concentration of large pieces of darkened or sooted daub (zone 4C) lie to 
the immediate south of the hearth; most of the bones of a single wild turkey were recovered in the midden zone south of the hearth.

Below the hearth and under the yellow sand floor, posts and pits were clearly defined in the buried E-horizon sandy loam. These include one support post (Fea. 75), about $30 \mathrm{~cm}$ in diameter, that extends to approximately $160 \mathrm{~cm}$ bs, more than $70 \mathrm{~cm}$ below the house floor. Fea. 76 is a pit about $50 \mathrm{~cm}$ in diameter that extends to at least $130 \mathrm{~cm}$ bs, and contains ash, charcoal, sherds, and animal bones.

There are several zones of mound fill above the yellow sand floor and Fea. 71, including zones 2, 2A, 3, and 4. All have significant amounts of charcoal and ash, particularly zones 2, 2A, and 3. The mound fill is approximately $50-60 \mathrm{~cm}$ in thickness overlying the Fea. 71 hearth. The amounts of charcoal and ash in the mound fill suggests that the structure under the mound had been burned after it was abandoned (deposits of ash and charcoal in the top of the Fea. 75 post suggests the post was pulled prior to the structure being set on fire), but the fire was extinguished by dumping the mound fill over the smoldering fire. The smothering of the fire also darkened the daub that was concentrated near the hearth (possibly part of a clay-lined screen around the hearth?).

After the structure had been covered by several zones of mound fill gathered in the vicinity of the earthen mound, a large post (Fea. 74) was then excavated by the Late Caddoan Titus phase people through the mound and the center of the hearth. The post hole to hold the post or large pole was $80 \mathrm{~cm}$ in diameter, and extended to $170 \mathrm{~cm}$ bs; this is approximately $80 \mathrm{~cm}$ below the yellow sand floor. A pole about $80 \mathrm{~cm}$ in diameter must have stood at least 10 - 20 feet above the mound.

Historic Caddo rituals concerning the use of tall poles have been discussed by Carter (1995:90-93, 96-99). According to Casanas, who wrote these words in 1691 , the Nabedache Caddo erected a pole in their village, and:

on it hangs a portion of everything they are offering to God. In front of the pole a fire is burning. Near by is a person who looks like a demon. He is the person who offers the incense to God, throwing tobacco and buffalo fat into the fire. The men collect themselves around the blaze; each one takes a handful of smoke and rubs his whole body with it. Each believes that, because of this ceremony, God will grant whatever he may ask -- whether it be the death of his enemy or swiftness to run. On other occasions the incense is not offered by burning in this way. In this case a kind of a burned pole is taken and set up by the fire. This pole, and the fat for the 
Volume 10(2)

incense -- which has

already been burned -- they

offer to God.

Whether the Fea. 74 post is an Itcha kaanah ('that kind of pole' [Carter 1995:92]) is unknown. However, its clear and intimate association with the large ashfilled hearth on the floor of the structure that was burned and covered by an earthen mound indicates that the excavation of the post hole and the erection of the pole was part and parcel of the mound construction rituals employed by the Titus phase Caddo peoples at the Pilgrim's Pride site.

The Pilgrim's Pride Corporation will protect and preserve the Area VII mound within the rendering plant construction area. An approximate $10 \mathrm{~m}$ buffer zone has been established around the remaining portions of the mound where no construction activities are to be permitted, and this area will be seeded with grass for landscaping purposes. The excavation areas have been filled in with a sterile red sand and clay mix.

\section{RESEARCH ISSUES}

There are two principal research issues concerning the Titus phase that our investigations will focus on: (1) establishing the settlement configuration of the community at the Pilgrim's Pride site; and (2) investigating the mortuary practices used by these prehistoric Caddo peoples. These are selected because the Pilgrim's Pride site is a habitation locale with associated burials and burial furniture, and the important information the site contains on these research issues will contribute to a better understanding of several of the study units proposed in the Historic Context on "The Development of Agriculture in Northeast Texas before A.D. 1600" (Perttula 1993:137-141). In particular, our investigations are designed to obtain extensive information on the character of Titus phase residential compounds -- the evidence of structures; the cemeteries and graves where the dead were buried; the middens where the animal and plant food refuse was discarded; and the material remains of tools and ceramics used in the procurement and processing of wild plant and animal foods and cultivated plants (i.e., maize, beans, and squash). We are also interested in determining the use of the small earthen mound identified during our investigations in the northeastern part of the site, particularly the sequence of use and destruction of the structure under the mound as well as its relationship to the remainder of the settlement and associated cemetery (well to the south of the mound). 


\section{Settlement Configuration}

While it is the case that the majority of the known Late Caddoan archeological sites are small settlements of farmsteads and hamlets with associated family cemeteries (Story 1990:338-339), few Titus phase residential sites have been investigated to ascertain their character (Perttula 1998:76-77). This is unfortunate because the individual Caddo household and hamlet are "the most fundamental building blocks of the Caddoan settlement system' (Story 1990:336). To understand these building blocks, from the perspective of how a single Titus phase residential site was internally organized, extensive largescale excavations, such as we have completed at the Pilgrim's Pride site, are essential.

We know that the residential sites were occupied by sedentary populations, probably for $1-2$ generations, and that they comprised dispersed communities along Big Cypress Bayou and its tributaries. The communities appear to have consisted of groups of households in small and large settlements that shared decision-making and frequently interacted socially. The settlements were probably composed of one to several family units or households, with house middens/daub concentrations, trash middens, and family cemeteries near the households. The bulldozer/backhoe stripping investigations we conducted at the site were designed to identify individual households and their associated activity areas, both within and outside of structures. Structures were recognized by circular patterns of postholes and interior support posts, along with possible interior benches and racks for sleeping and aboveground storage purposes, as well as interior smudge pits. We expected that there were other activities besides trash disposal that occurred outside the houses, including work and cooking areas, ramadas, and above-ground granaries that may be marked by trash-filled pits, hearths, and posts.

The distribution of the more than 350 features excavated at the Pilgrim's Pride site will be used to define individual households. In conjunction with the detailed stylistic analysis of ceramic decorative elements designed to isolate contemporaneous or sequent households in the large settlement, and the absolute dates from a variety of features, these data bases will be employed to determine the age and intrasite chronological relationships of components and ceramic assemblages at the site; the occupational history of the site during the Titus phase as reconstructed from ceramic stylistic analyses and feature patterning; and structure/feature relationships and community patterns through time. In essence, what the analyses are directed towards is establishing whether the Titus phase settlement at the Pilgrim's Pride site is one large contemporaneous and permanent settlement of several functionally equivalent households, or is instead comprised of a more complex mixture or related and/or unrelated households, burials, and mound center occupying an upland landform over several generations. 
Volume 10(2)

\section{Mortuary Practices}

The study of Titus phase mortuary practices at the Pilgrim's Pride site has the potential to contribute important information on the social differences that existed among these prehistoric Caddo populations. In particular, the examination of the complexity of mortuary behavior (i.e., the energy invested in the mortuary rituals, the amounts of grave goods placed with the dead, the kinds of grave goods placed with the dead, and the locale where the dead were buried) in family and community cemeteries indicates that the mortuary treatment of the elite and non-elite in Titus phase times was quite diverse (Perttula and Nelson 1998c:381-392).

The recent analysis of more than 116 Titus phase cemeteries in the Big Cypress Creek, Sabine River, and Sulphur River drainages indicates that they are not uniformly distributed across the basins; the sizes of cemeteries and burial grounds vary considerably by stream drainage; and the cemeteries are not uniformly concentrated on particular stream drainages (Perttula and Nelson 1998c:358). In the Titus phase heartland -- roughly the area of Big Cypress Creek between the confluence of Little and Big Cypress creeks to the southeast and the confluence of Brushy Creek and Big Cypress Creek to the west (Perttula and Nelson 1998c: Figure 159) -- Titus phase cemeteries (including family cemeteries and large community cemeteries) are much more prevalent along eastward-flowing tributaries of Big Cypress Creek (such as Walkers Creek) than they are on Big
Cypress Creek itself. This probably reflects the overall density of Titus phase populations across the Titus phase heartland. From these data, then, we had every reason to expect that family and community cemeteries from a relatively dense Titus phase population would be present along Walkers Creek, and that cemeteries would be identified at the Pilgrim's Pride site during our investigations.

Because Titus phase burials have been identified at the Pilgrim's Pride site, our first concern will be to document the number of individual interments and whether they can be associated with individual households, the kinds of grave goods associated with the interments and the energy invested in burial (i.e., shaft tombs versus individual extended grave pits), the sex and age of the individuals should human remains be preserved, and the boundaries and orientation of formal cemetery areas. From this information, we can examine the social hierarchical character of the households within the settlement, as well as within the larger community, by comparison with other Titus phase family and community cemeteries (see Thurmond 1990; Turner 1992; Perttula and Nelson 1998c). The detailed examination of ceramic styles and Ripley Engraved rim motifs on the vessels placed as grave goods will also provide sufficient information to establish the broader social affiliations of the Pilgrim's Pride site households. 
If the burials at Pilgrim's Pride represented interments in family cemeteries, then we expected to recover evidence of 10 - 30 individual interments from family groups -- both male and female, as well as juvenile and child burials -- with comparable quantities and kinds of grave goods, usually an assortment of whole vessels, along with pipes and celts in the graves of adult men. Although the absolute size of the cemetery is unknown because its southern end was disturbed by road construction, an estimate of approximately 30 burials in the cemetery seems reasonable based on the known distribution of the burials and burial rows. Titus phase community cemeteries should have more than $70-100$ burials, the products of interments from a number of communities in the vicinity, and they must reflect a wider community-based participation in ceremonial and mortuary activities (Story 1990:338-339). The community cemeteries will not only have larger numbers of interments, but they will contain the burials of the social elite in the community, typically adult males (Perttula and Nelson 1998c:381; Thurmond 1990). It does not appear that a community cemetery is present at the Pilgrim's Pride site. If there are probable high status Titus phase burials at the Pilgrim's Pride site, they ought to include one of the following, based on the 18 known Titus phase cemeteries (Perttula and Nelson 1998c: Figure 158) with presumed high status burials: burial in a shaft tomb; burial in a mound; burials with large chipped Galt bifaces (and possible ear spools?); individual extended supine burials with large quantities of grave goods, especially quivers of arrowpoints; and double extended supine burials with quantities of grave goods, particularly ceramic vessels. Based on these criteria, burial features 503 and 504 have been tentatively identified as high status burials in the Pilgrim's Pride cemetery.

\section{CONCLUSIONS}

During the course of 22 days of field work in January and February 1999, archeological investigations were completed at the Pilgrim's Pride site (41CP304) by Archeological \& Environmental Consultants (Austin, Texas). The Pilgrim's Pride site is located within the proposed rendering plant area of the Walker Creek project being developed by Pilgrim's Pride Corporation, and the site will be destroyed by the proposed construction activities.

Our archeological investigations in- cluded the extensive machine stripping of six areas of the site (totaling about 2.4 acres), followed by the identification and excavation of more than 350 features in these areas. The features -- including burials, structure posthole patterns, and numerous pits -- indicate that, during the Late Caddoan Titus phase, the Pilgrim's Pride site was a residential site that also had a large cemetery spatially segregated from the three rises (areas I-III) that did have substantial amounts of residential archeological deposits. Additional work 
Volume 10(2)

was also conducted in Area VII to investigate a Titus phase earthen mound capping a burned structure. The identification of an earthen mound at the Pilgrim's Pride site indicates that it was a center for civic and ceremonial rituals for the Titus phase community in the Walkers
Creek and Big Cypress Creek drainage. Archeological survey and shovel testing across the Walker Creek project area (Perttula and Nelson 1998a) indicates that there was a substantial Titus phase population in the area.

\section{REFERENCES CITED}

Carter, C. E.

1995 Caddo Indians: Where We Come

From. University of Oklahoma Press, Norman.

Perttula, T. K.

1993 The Development of Agriculture in Northeast Texas before A.D. 1600. In Archeology in the Eastern Planning Region, Texas: A Planning Document, edited by $\mathrm{N}$. A. Kenmotsu and T. K. Perttula, pp. 121-146. Cultural Resource Management Report 3 . Department of Antiquities Protection, Texas Historical Commission, Austin.

1998 Late Caddoan Societies in the Northeast Texas Pineywoods. In The Native History of the Caddo: Their Place in Southeastern Archeology and Ethnohistory, edited by T. K. Perttula and J. E. Bruseth, pp. 69-90. Studies in Archeology 30. Texas Archeological Research Laboratory, The University of Texas at Austin.
Perttula, T. K. and B. Nelson

1998a Archeological Survey Investigations of Selected Parts of the Walker Creek Project Area for Pilgrim's Pride Corporation, Camp County, Texas. Report of Investigations No. 22. Archeological \& Environmental Consultants, Austin.

1998b Preliminary Description of the Late Caddoan Vessels from the Pilgrim's Pride Site (41CP304). Archeological \& Environmental Consultants, Austin.

1998c Titus Phase Mortuary Practices in the Northeast Texas Pineywoods and Post Oak Savanna. In Analysis of the Titus Phase Mortuary Assemblage at the Mockingbird Site 'Kahbakayammaahin' (41TT550), by T. K. Perttula, M. Tate, H. Neff, J. W. Cogswell, M. D. Glascock, E. Skokan, S. Mulholland, R. Rogers, and B. Nelson, pp. 328-401. Document No. 970849. Espey, Huston \& Associates, Inc., Austin. 
Story, D. A.

1990 Cultural History of the Native Americans. In The Archeology and Bioarcheology of the Gulf Coastal Plain, by D. A. Story, J. A. Guy, B. A. Burnett, M. D. Freeman, J. C. Rose, D. G. Steele, B. W. Olive, and K. J. Reinhard, pp. 163366. 2 Vols. Research Series No. 38. Arkansas Archeological Survey, Fayetteville.

Thurmond, J. P. 1990 Archeology of the Cypress Creek
Drainage Basin, Northeastern Texas and Northwestern Louisiana. Studies in Archeology 5. Texas Archeological Research Laboratory, The University of Texas at Austin.

Turner, R. L., Jr.

1992 Prehistoric Mortuary Remains at the Tuck Carpenter Site, Camp County, Texas. Studies in Archeology 10. Texas Archeological Research Laboratory, The University of Texas at Austin. 